\title{
Pearls \& Oy-sters: Moyamoya Vasculopathy and Its Association With Congenital Heart Disease
}

Justus Osterloh, Christian Heim, MD, Gabriela Siedler, MD, Tobias Engelhorn, MD, Arnd Doerfler, MD, Stefan Schwab, MD, and Bernd Kallmünzer, MD

Neurology ${ }^{\circledR}$ 2021;96:e2896-e2898. doi:10.1212/WNL.0000000000012049
Correspondence

Mr. Osterloh

justus.osterloh@fau.de

\section{Pearls}

- Moyamoya vasculopathy (MMV) is characterized by a progressive, usually bilateral narrowing of the terminal segment of the internal carotid artery or the initial segments of the anterior/middle cerebral artery leading to occlusion and formation of a fragile network of abundant collateral vessels with a high risk of stroke.

- Moyamoya syndrome (MMS) is rare and differs from primary idiopathic Moyamoya disease (MMD) as it develops secondary to an underlying acquired or inherited condition, including cranial radiotherapy, neurofibromatosis type I, Down syndrome, sickle cell disease, or congenital heart disease.

\section{Oy-sters}

- In addition to embolic stroke, patients with congenital heart disease carry an elevated risk for vascular cognitive impairment, MMS, cerebral aneurysms, and intracranial hemorrhage.

- In order to avoid severe cerebrovascular complications, noninvasive arterial imaging offers an option for the early detection and initiation of preventive measures in patients with congenital heart disease.

A 48-year-old man presented to our emergency department 2 hours after acute onset of headache and language abnormalities. The patient had a medical history of congenital heart disease comprising aortic coarctation ( $\mathrm{CoA})$, bicuspid aortic valve, and ectasia of the ascending aorta. He had undergone surgical treatment at 1 year of age with resection of $\mathrm{CoA}$ and end-toend anastomosis. At age 9 years, an aortic patch plastic was implanted due to aortic restenosis. The subsequent physical and mental development during childhood and adolescence was unremarkable. At age 29 years, he underwent replacement of the ascending aorta by a $24 \mathrm{~mm}$ Hemashield prothesis and in the later course, implantation of a mechanical aortic heart valve ( $23 \mathrm{~mm}, \mathrm{SJM}$ ). Since then, the patient had been on oral anticoagulation with phenprocoumon. Additional medication included antihypertensive treatment with metoprolol and ramipril. Blood pressure readings were taken on a daily basis, showing normotension during the months ahead of the event. The patient had a history of smoking (10 pack-years) but quit at age 28 . He did not abuse any other drugs. Prior to the current symptom onset, the patient reported a good state of health and worked full-time employed as a salesperson.

Neurologic examination at the time of admission revealed moderate global aphasia (NIH Stroke Scale score 4). An initially performed cranial CT scan showed a temporal intracerebral hematoma of $18 \mathrm{~mL}(3.3 \times 3.0 \times 3.6 \mathrm{~cm})$ in the left hemisphere (figure, A). In addition, old lacunar infarcts in the areas of the caudate nucleus and basal ganglia were visible and a cranial CT angiogram revealed weak anterior circulation bilaterally. On admission, blood pressure measurement unveiled only mild hypertension $(140 / 90 \mathrm{~mm} \mathrm{Hg})$ and the international normalized ratio (INR) measured 2.9. For anticoagulation reversal, the patient received 3,000 IU of 4-factor prothrombin complex concentrate IV (INR dropped to 1.1). Digital subtraction

From the Departments of Neurology (J.O., G.S., S.S., B.K.) and Neuroradiology (T.E., A.D.), University Hospital Erlangen, Friedrich-Alexander-University Erlangen-Nuremberg (FAU); and Department of Cardiac Surgery (C.H.), University of Erlangen-Nuremberg, Germany.

Go to Neurology.org/N for full disclosures. Funding information and disclosures deemed relevant by the authors, if any, are provided at the end of the article. 


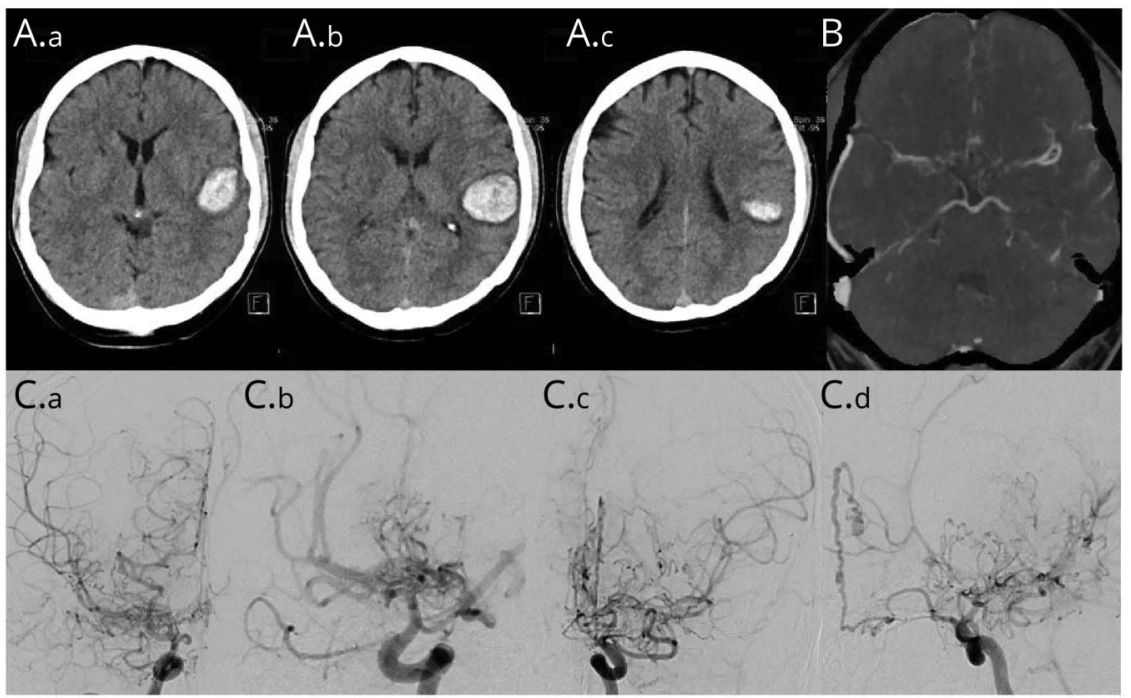

(A.a-A.c) CT shows a well-defined, hyperattenuating temporal lesion with a volume of 18 $\mathrm{mL}$ in the left hemisphere. (B) Axial view of a CT angiogram demonstrates weak anterior circulation. (C.a-C.d) Cerebral angiogram exposes bilateral occlusion of the terminal carotid arteries and proximal segments of the medial cerebral arteries as well as a fine anastomotic network of collateral vessels.

angiography performed 2 days after admission showed a bilateral high-grade stenosis of the terminal carotid arteries including the proximal segments of the medial cerebral arteries and a surrounding network of small collaterals (figure, C.a-C.d) with no signs of cerebral aneurysms. The analysis of CSF was normal. There was no evidence for cerebral or systemic vasculitis or rheumatic or infectious disease by clinical examination and diagnostic testing. On echocardiography, the function of the left ventricle and the mechanical aortic valve prosthesis appeared normal. The clinical course was uneventful; oral anticoagulation was reinitiated 12 days after admission. On discharge (day 15), the patient had mild anomia and continued in rehabilitative care.

\section{Discussion}

MMV is characterized by a chronic and progressive occlusion of the terminal carotid arteries or the initial segments of the anterior/middle cerebral arteries, evoking a fragile network of surrounding collateral vessels at the base of the brain. A characteristic finding on vascular imaging is the eponymous smoke-like formation of blood vessels and the first describers therefore titled the condition Moyamoya (Japanese for "puff of smoke"). 'The occurrence of MMV shows relevant regional differences with a comparably high incidence in East Asia and a low incidence in Europe and North America. ${ }^{2}$ Its prevalence in Japan has been estimated up to 3/100,000,3 10 times higher than observed in Europe. ${ }^{4}$

Whereas underlying mechanisms of MMV remain to be elucidated, a genetic predisposition of the disease has been recognized. Recent studies were able to identify RNF213 as an important susceptibility gene and associated gene loci on chromosome $3,6,8$, and 17 have been found in a chromosomal search for familial MMV. ${ }^{5}$ Patients with symptomatic MMV commonly present with TIA, ischemic stroke, or intracerebral hemorrhage $(\mathrm{ICH})$. Other neurologic symptoms include migraine-like headaches, seizures, or cognitive dysfunction. ${ }^{2}$ Cerebral angiography is considered the gold standard for the diagnosis of MMV and the system most commonly used for classification is the Suzuki staging system. ${ }^{1}$

After diagnosis of MMV, a thorough investigation of precipitating factors is necessary. In absence of these factors, MMV is classified as idiopathic (MMD), while the term MMS applies to only $10 \%-20 \%$ of cases where an underlying acquired or inherited condition is associated with the cerebral vascular occlusion phenomenon. ${ }^{2}$ The most common associated disorders are neurofibromatosis type 1, Down syndrome, sickle cell disease, and cranial radiotherapy. ${ }^{2,6}$ Another, albeit rare, cause of MMS is congenital heart disease, as illustrated in the presented case. Whereas the association of MMV with CoA has been reported, ${ }^{7}$ it remains unresolved to what extent the hemodynamic changes with long-lasting hypertension restricted to the upper body typically seen in patients prior to surgical repair of CoA contribute to the cerebrovascular occlusion. Both findings could also result from a systemic vasculopathy or systemic congenital malformation. ${ }^{7}$ A novel hypothesis proposes that defects of neural crest cells during embryogenesis could contribute to a simultaneous occurrence of cardiac and cephalic pathologies. ${ }^{8}$

Along with MMV, the association of cardiovascular and cerebrovascular diseases has also been reported in PHACE syndrome and ACTA2 mutations syndrome. 8 Apart from MMV, patients with $\mathrm{CoA}$ are exposed to an elevated risk for cerebral aneurysms. Vascular imaging prior to the occurrence of neurologic symptoms offers an option to identify underlying conditions early and evaluate primary preventive measures. 
Optimal treatment of hypertension, cessation of smoking, and reduction of alcohol consumption should be initiated. In addition, endovascular or neurosurgical interventions might be indicated for primary treatment in patients with cerebral aneurysms. In case of MMV, evaluation in a specialized neurovascular center is recommended.

Symptomatic progression has been estimated to occur in up to two-thirds of patients with MMV over a 5-year period ${ }^{2}$ and although the risk of intracerebral bleeding or stenosis-associated symptoms is high, therapeutic options remain limited. There is no evidence-based medical treatment with proven benefit. The use of antithrombotic medication consisting of antiplatelet agents or anticoagulation is discussed controversially. ${ }^{9}$ In the patient presented in this report, the mechanical aortic valve demanded the use of phenprocoumon for oral anticoagulation, which was re-established 12 days after ICH onset. Otherwise, the use of vitamin $\mathrm{K}$ antagonists would hardly be justifiable in symptomatic MMS with prior ICH. Surgical treatment of MMV constitutes a therapeutic option for selected patients at a low level of scientific evidence: a smaller randomized trial as well as a recent meta-analysis suggest a marginal preventive benefit with neurosurgical revascularization, whereas the effect was more pronounced among patients with hemorrhagic MMV. ${ }^{10,11}$ The most common surgical technique is direct revascularization with the superficial temporal artery to anterior cerebral artery/middle cerebral artery anastomosis. Indirect revascularization procedures rely on the use of well-blood-supplied tissues to induce neovascularization of the cortical surface. ${ }^{2}$

Deeper insights into the pathophysiologic mechanisms and the genetic background of MMV are needed for the development of new, causal treatment options and individualized preventive measures.

\section{Study Funding}

No targeted funding reported.

\section{Disclosure}

The authors report no disclosures relevant to the manuscript. Go to Neurology.org/N for full disclosures.

Appendix Authors

\begin{tabular}{|c|c|c|}
\hline Name & Location & Contribution \\
\hline $\begin{array}{l}\text { Justus } \\
\text { Osterloh }\end{array}$ & $\begin{array}{l}\text { Department of Neurology, } \\
\text { University Hospital } \\
\text { Erlangen, Friedrich- } \\
\text { Alexander-University } \\
\text { Erlangen-Nuremberg } \\
\text { (FAU), Germany }\end{array}$ & $\begin{array}{l}\text { Drafting/revision of the } \\
\text { manuscript for content, } \\
\text { including medical writing } \\
\text { for content; major role in } \\
\text { the acquisition of data; } \\
\text { analysis or interpretation of } \\
\text { data }\end{array}$ \\
\hline
\end{tabular}

\begin{tabular}{|c|c|c|}
\hline Name & Location & Contribution \\
\hline $\begin{array}{l}\text { Christian } \\
\text { Heim, MD }\end{array}$ & $\begin{array}{l}\text { Department of Cardiac } \\
\text { Surgery, University of } \\
\text { Erlangen-Nuremberg, } \\
\text { Germany }\end{array}$ & $\begin{array}{l}\text { Drafting/revision of the } \\
\text { manuscript for content, } \\
\text { including medical writing } \\
\text { for content }\end{array}$ \\
\hline $\begin{array}{l}\text { Gabriela } \\
\text { Siedler, MD }\end{array}$ & $\begin{array}{l}\text { Department of Neurology, } \\
\text { University Hospital } \\
\text { Erlangen, Friedrich- } \\
\text { Alexander-University } \\
\text { Erlangen-Nuremberg } \\
\text { (FAU), Germany }\end{array}$ & $\begin{array}{l}\text { Drafting/revision of the } \\
\text { manuscript for content, } \\
\text { including medical writing } \\
\text { for content }\end{array}$ \\
\hline $\begin{array}{l}\text { Tobias } \\
\text { Engelhorn, } \\
\text { MD }\end{array}$ & $\begin{array}{l}\text { Department of } \\
\text { Neuroradiology, } \\
\text { University Hospital } \\
\text { Erlangen, Friedrich- } \\
\text { Alexander-University } \\
\text { Erlangen-Nuremberg } \\
\text { (FAU), Germany }\end{array}$ & $\begin{array}{l}\text { Drafting/revision of the } \\
\text { manuscript for content, } \\
\text { including medical writing } \\
\text { for content }\end{array}$ \\
\hline $\begin{array}{l}\text { Arnd } \\
\text { Doerfler, } \\
\text { MD }\end{array}$ & $\begin{array}{l}\text { Department of } \\
\text { Neuroradiology (T.E., } \\
\text { A.D.), University Hospital } \\
\text { Erlangen, Friedrich- } \\
\text { Alexander-University } \\
\text { Erlangen-Nuremberg } \\
\text { (FAU), Germany }\end{array}$ & $\begin{array}{l}\text { Drafting/revision of the } \\
\text { manuscript for content, } \\
\text { including medical writing } \\
\text { for content }\end{array}$ \\
\hline $\begin{array}{l}\text { Stefan } \\
\text { Schwab, MD }\end{array}$ & $\begin{array}{l}\text { Department of Neurology, } \\
\text { University Hospital } \\
\text { Erlangen, Friedrich- } \\
\text { Alexander-University } \\
\text { Erlangen-Nuremberg } \\
\text { (FAU), Germany }\end{array}$ & $\begin{array}{l}\text { Drafting/revision of the } \\
\text { manuscript for content, } \\
\text { including medical writing } \\
\text { for content }\end{array}$ \\
\hline $\begin{array}{l}\text { Bernd } \\
\text { Kallmünzer, } \\
\text { MD }\end{array}$ & $\begin{array}{l}\text { Department of Neurology, } \\
\text { University Hospital } \\
\text { Erlangen, Friedrich- } \\
\text { Alexander-University } \\
\text { Erlangen-Nuremberg } \\
\text { (FAU), Germany }\end{array}$ & $\begin{array}{l}\text { Drafting/revision of the } \\
\text { manuscript for content, } \\
\text { including medical writing for } \\
\text { content; major role in the } \\
\text { acquisition of data; analysis } \\
\text { or interpretation of data }\end{array}$ \\
\hline
\end{tabular}

\section{References}

1. Suzuki J, Takaku A. Cerebrovascular "moyamoya" disease: disease showing abnorma net-like vessels in base of brain. Arch Neurol 1969;20:288-299.

2. Scott RM, Smith ER. Moyamoya disease and moyamoya syndrome. N Engl J Med 2009;360:1226-1237.

3. Kuriyama S, Kusaka Y, Fujimura M, et al. Prevalence and clinicoepidemiological features of moyamoya disease in Japan: findings from a nationwide epidemiological survey. Stroke 2008;39:42-47.

4. Yonekawa Y, Ogata N, Kaku Y, Taub E, Imhof HG. Moyamoya disease in Europe, past and present status. Clin Neurol Neurosurg 1997;99(suppl 2):S58-S60.

5. Kamada F, Aoki Y, Narisawa A, et al. A genome-wide association study identifies RNF213 as the first Moyamoya disease gene. J Hum Genet 2011;56:34-40.

6. Ullrich NJ, Robertson R, Kinnamon DD, et al. Moyamoya following cranial irradiation for primary brain tumors in children. Neurology 2007;68:932-938.

7. Christiaens FJ, Van den Broeck LK, Christophe C, Dan B. Moyamoya disease (moyamoya syndrome) and coarctation of the aorta. Neuropediatrics 2000;31:47-48.

8. Komiyama M. Cardio-cephalic neural crest syndrome: a novel hypothesis of vascular neurocristopathy. Interv Neuroradiol 2017;23:572-576.

9. Oki K, Katsumata M, Izawa Y, et al. Trends of antiplatelet therapy for the management of moyamoya disease in Japan: results of a nationwide survey. J Stroke Cerebrovasc Dis 2018;27:3605-3612.

10. Miyamoto S, Yoshimoto T, Hashimoto N, et al. Effects of extracranial-intracranial bypass for patients with hemorrhagic moyamoya disease: results of the Japan Adult Moyamoya Trial. Stroke 2014;45:1415-1421.

11. Wouters A, Smets I, Van den Noortgate W, Steinberg GK, Lemmens R. Cerebrovascular events after surgery versus conservative therapy for moyamoya disease: a meta-analysis. Acta Neurol Belg 2019;119:305-313. 


\section{Neurology}

\section{Pearls \& Oy-sters: Moyamoya Vasculopathy and Its Association With Congenital Heart Disease \\ Justus Osterloh, Christian Heim, Gabriela Siedler, et al.}

Neurology 2021;96;e2896-e2898 Published Online before print April 14, 2021

DOI 10.1212/WNL.0000000000012049

This information is current as of April 14, 2021

\section{Updated Information \&} Services

References

Subspecialty Collections

Permissions \& Licensing

Reprints including high resolution figures, can be found at: http://n.neurology.org/content/96/23/e2896.full

This article cites 11 articles, 3 of which you can access for free at: http://n.neurology.org/content/96/23/e2896.full\#ref-list-1

This article, along with others on similar topics, appears in the following collection(s):

\section{Aphasia}

http://n.neurology.org/cgi/collection/aphasia

Intracerebral hemorrhage

http://n.neurology.org/cgi/collection/intracerebral_hemorrhage

Information about reproducing this article in parts (figures,tables) or in its entirety can be found online at:

http://www.neurology.org/about/about_the_journal\#permissions

Information about ordering reprints can be found online:

http://n.neurology.org/subscribers/advertise

Neurology ${ }^{\circledR}$ is the official journal of the American Academy of Neurology. Published continuously since 1951, it is now a weekly with 48 issues per year. Copyright @ 2021 American Academy of Neurology. All rights reserved. Print ISSN: 0028-3878. Online ISSN: 1526-632X.

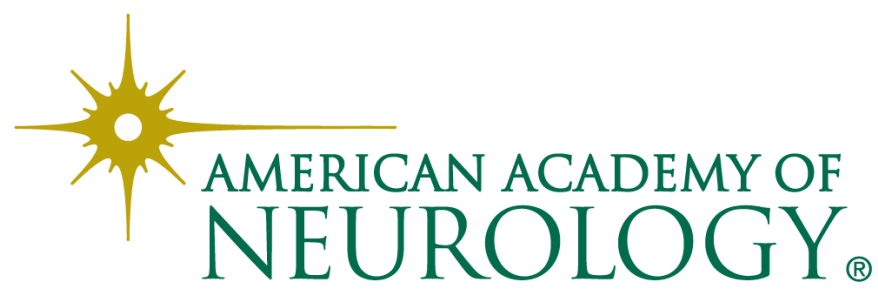

